V. Shamrai, Dr of Law, Associate Prof.

I. Sliusarenko, PhD (Law), Associate Prof.

Taras Shevchenko National University of Kyiv, Kyiv, Ukraine

\title{
TRANSFORMATION OF STATE SOVEREIGNTY IN MODERN CONDITIONS OF CONSTITUTIONAL LAW DEVELOPMENT
}

The article deals with theoretical and methodological approaches to the essence of the state sovereignty in modern conditions of legal globalization and European interstate integration from the point of view of searching for effective means of complex legal modernization of society.

The author analyzes the legal content of this category, shows its specific features, reveals the importance of the processes of improving the basic elements of social relations and constitutional modernization of society and the state in modern conditions of legal globalization and European interstate integration.

The need for further improvement of constitutional and legal regulation of the most important social relations as a key direction of legal modernization of social relations in a modern democratic state based on the fundamental foundations of European constitutionalism is underlined.

At the same time, at the doctrinal level, there is no doubt that the Constitution of Ukraine has a certain degree of almost all the well-known features of the world, in particular, the European, constitutions.

Summarizing the above, we consider it necessary to highlight the following main formal and legal features of the Constitution of Ukraine, which is the fundamental ground for modern constitutional and legal reform in our state: 1) a special subject accepting (people's character); 2) the fundamental (institutional) nature; 3) stability is coupled with dynamism; 4) reality; 5) formal and legal properties: the Constitution - the Fundamental Law of Ukraine; its highest legal force; Constitution - the legal base of legislation; A special procedure for making and amending; Special content and structure of the Constitution; Direct effect of its norms.

This list is not exhaustive, but in our opinion, it is optimal for defining the main tasks and principles of constitutional and legal reform in the current conditions of legal globalization and European interstate integration.

Thus, with the improvement of the Constitution of Ukraine as the main source of constitutional law of Ukraine, it is necessary to focus not only on the modernization of certain institutions that regulate it, but also on the strengthening of its legal properties in general.

In other words, the leading role of the Constitution in the system of sources of constitutional law of Ukraine is due to its inherent legal properties, ensuring their effectiveness in society and is a priority task of modern constitutional and legal reform.

Thus, under the constitutional and legal reform, in today's conditions of legal globalization and European interstate integration, it is necessary to reform of the sphere of constitutional law directly as a leading national branch of law of Ukraine, the formally-legal improvement and improvement of the constitutional legal material at all its system levels, as provisions, institutions, sub-sectors and industry as a whole.

It should also be noted that the subject and object of the branch of constitutional law varies in modern conditions under the influence of a whole range of objective factors of legal and political reality, in particular, it refers to the processes of legal globalization and intergovernmental integration, which, in turn, internally causes the emergence of new branches and subnets of national law, strengthening the internationalization of constitutional law and the constitutionality of international and European law, the adaptation of domestic constitutional laws and to basic European legal standards as a prerequisite quality of the constitutional and legal reform in accordance with objectively existing conditions of society.

The need for further improvement of the constitutional and legal regulation of the most important social relations as the most important line of public power in the context of the perception of the European legal system by the national legal system of Ukraine is underlined.

Keywords: constitutional law, global constitutionalism, legal modernization, society, state sovereignty.

Bulletin of Taras Shevchenko National University of Kyiv. Legal Studies, 2021; 1 (116): 54-66

удК:341.96: $347.65 / 68$

DOI: https:doi.org/10.17721/1728-2195/2021/1.116-14
ISSN 1728-2195

(C) Taras Shevchenko National University of Kyiv, Publishing center "Kyiv University", 2020

\section{РЕЦЕНЗІЯ НА МОНОГРАФІЮ \\ I. А. Діковської "Міжнародне спадкування у ЄС та Україні: напрями адаптації права України до права ЄС" (Київ, Алерта, 2020)}

Потреби сучасного життя, яке, серед іншого, характеризується високою мобільністю, можливістю вільно обирати країну проживання, обумовлюють розвиток міжнародного спадкового права у світі в останні роки. Так, наприклад, у більшості країн $€ С$, починаючи 317 серпня 2015 р., визначення права, що застосовується до спадкових відносин з іноземним елементом, міжнародної юрисдикції у спадкових справах, визнання і виконання іноземних рішень у таких справах, а також деякі інші питання, що виникають під час міжнародного спадкування, регулюються Регламентом (ЄС) № 650/2012 Європейського парламенту та Ради від 4 липня 2012 року щодо юрисдикції, застосовуваного права, визнання та виконання рішень та прийняття і виконання аутентичних інструментів у спадкових справах та про створення Європейського спадкового сертифрікату (надалі - Спадковий регламент). Поява цього документу спричинила публікацію багатьох статей, монографій, що фокусуються на можливих способах регулювання тих чи інших питань міжнародного спадкового права.

Водночас норми міжнародних договорів та Закону України "Про міжнародне приватне право" від 23 червня 2005 р. № 2709 (надалі - ЗУ "Про МПрП"), які визна- чають право, що застосовуються до спадкових відносин, а також стосуються інших питань, важливих для регулювання міжнародного спадкування характеризуються певними прогалинами, деякі з них - невизначеністю та архаїчністю, що, безумовно, не ускладнює реалізацію спадкових прав.

Відтак, монографрія, яка має на меті порівняти правове регулювання міжнародного спадкування у ЄС та Україні та запропонувати його удосконалення в Україні, $€$ актуальною.

Книга складається з 15 розділів, у яких, зокрема, розглядаються проблемні питання застосування джерел регулювання міжнародних спадкових відносин Україні та країнах ЄС; визначення міжнародної юрисдикції у спадкових справах згідно зі Спадковим регламентом, міжнародними договорами України та ЗУ "Про МПрП"; визначення права, що застосовується до спадкування відповідно до Спадкового регламенту та колізійних норм, які діють в Україні; визнання та надання дозволу на виконання іноземних рішень за Спадковим регламентом, правом окремих держав-членів ЄС, міжнародними договорами України та ЗУ "Про МПрП"; прийняття аутентичних документів, виданих за кордоном для 
оформлення спадщини за Спадковим регламентом, національним правом окремих держав-членів ЄС та правом України, правова природа та обіг Європейського спадкового сертифрікату.

Ряд висновків, здійснених у монографії, заслуговують на підтримку. Наприклад, про необхідність визначення у зУ "Про МПрП" кола питань, які охоплюються спадковим статутом; про доречність удосконалення колізійного регулювання форми заповітів; про потребу у колізійному регулюванні спадкових угод у ЗУ "Про МПрП".

Крім того, вдалою $є$ пропозиція автора про встановлення у ЦПК України загального правила про те, що визнання рішень, які не підлягають примусовому виконанню, не потребує дотримання спеціальної процедури. Ідея про сприйняття підходу, за якого іноземні рішення, які не набули законної сили, можуть визнаватися, якщо вони не потребують примусового виконання також заслуговує на увагу. Обґрунтованими $є$ пропозиції про вилучення окремих підстав для відмови у визнанні і виконанні іноземних судових рішень із ЦПК України. У роботі вдало виділені ознаки аутентичних документів, виданих за кордоном, які можуть використовуватися для оформлення спадкування, а також містяться інші важливі висновки щодо аутентичних документів.

Книга буде корисною для всіх, хто має намір поглибити знання з міжнародного спадкового права, міжнародного приватного права, міжнародного цивільного процесу, права ЄC.

Received: $05 / 02 / 2021$ Accepted: $12 / 02 / 2021$

N. Fedorchenko, Dr of Law, Prof.

Kyiv University of Tourism, Economics and Law, Kyiv, Ukraine

\section{MONOGRAPH REVIEW OF DR. IRYNA DIKOVSKA "INTERNATIONAL SUCCESSION IN THE EU AND UKRAINE: DIRECTIONS FOR ADAPTATION OF UKRAINIAN LAW TO THE EU LAW" (KYIV, ALERTA, 2020).}

The review evaluates the content of the monography. It has been concluded that the idea of the monograph is relevant since the rules of international treaties of Ukraine (namely, bilateral agreements on legal assistance) and the Law of Ukraine on Private International Law (hereinafter: PILA) contain some gaps and uncertain provisions regarding international succession law issues which need to be filled or revised respectively. We support the author's suggestion to make such amendments taking into consideration Regulation (EU) No 650/2012 of the European Parliament and of the Council of 4 July 2012 on jurisdiction, applicable law, recognition and enforcement of decisions and acceptance and enforcement of authentic instruments in matters of succession and on the creation of a European Certificate of Succession, as well as, the EU Private International Law doctrine and solutions to international succession law issues in national law of some the EU Member States.

The book consists of 15 chapters which focus on the determination of international jurisdiction in succession matters; determination of the law applicable to succession relations with a foreign element; recognition and enforcement of foreign decisions in succession matters; acceptance of authentic documents created abroad.

Many author's ideas seem appropriate. They include the suggestions to determine the scope of law applicable to the succession in PILA; to amend the conflict of laws rules applicable to the form of wills; to include in PILA conflict of laws rules regarding succession agreements; to amend some rules of Civil Procedural Code of Ukraine applicable to recognition and enforcement of foreign decisions in civil matters and others.

It was concluded that the monograph would useful for everyone who intends to increase his or her knowledge in international succession law, private international law, international civil procedure. 